\title{
Influence of Vineyard Vegetational Borders on Western Grape Leafhopper (Erythroneura elegantula Osborn), its Egg Parasitoids (Anagrus spp.) and Generalist Insect Predators
}

\author{
Michael J. Costello ${ }^{*}$, Ann Thrupp ${ }^{2}$, Glenn McGourty ${ }^{3}$ \\ (1) Horticulture and Crop Science Department, California Polytechnic State University, San Luis Obispo, CA 93407, USA \\ (2) Fetzer Vineyards, Hopland, CA 95449, USA \\ (3) University of California, Cooperative Extension, Ukiah, CA 95482, USA
}

Submitted for publication: October 2020

Accepted for publication: January 2021

Key words: Vitis vinifera, diversity, conservation, biological control, Orius, Leptothrips

\begin{abstract}
Studies have shown that vegetational diversity in or around cropping systems can enhance natural enemy abundance, although the impact on herbivores is less certain. We studied the influence of vineyard vegetational borders on density of the western grape leafhopper, Erythroneura elegantula, its major parasitoids, Anagrus spp., and two generalist predators, Orius spp. and Leptothrips mali. Two study vineyards had planted, perennial flowering hedgerows, one bordered a natural riparian zone, and one had a sparse border of native trees. From April to September 2007, we counted leafhopper nymphs and adults of Anagrus spp., Orius spp. and L. mali within $10 \mathrm{~m}$ of the border, and at additional $20 \mathrm{~m}$ intervals up to $90 \mathrm{~m}$. At two sites with a diverse border, leafhopper density was stable nearest the border; at other distances leafhopper density decreased between the first and second generations. This effect was not seen at the sparse border site. Anagrus spp. density was enhanced at one site with a diverse border, but only late season. There was no border effect on the generalist insect predators, by site or early vs. late season. Regression analysis showed a positive relationship between leafhopper and Anagrus spp. density, suggesting that the parasitoids were responding to higher leafhopper density. We conclude that, depending on the nature of the border vegetation, there can be an effect on leafhopper nymphal density, but in this study there is no evidence that it was due to natural enemies.
\end{abstract}

\section{INTRODUCTION}

Vegetational diversity and its effects on insect pests and their natural enemies have been studied in a wide variety of cropping systems (see reviews by Andow, 1991; Landis et al., 2000; Letourneau et al., 2011). Ratnadass et al. (2012) identify eight pathways in which vegetational diversity can impact agricultural pests, which include top down effects on arthropods through natural enemy conservation. The concept that non-crop plantings can influence arthropod natural enemies, known as the enemies hypothesis (Root, 1973; Russell, 1989), says that the alternative vegetation can provide alternate food sources (Wäckers et al., 2007), or shelter and overwintering sites (Landis et al., 2000). Theorists have suggested that agroecosystems should mimic more diverse natural ecosystems, which will improve the stability of insect communities at higher trophic levels (Haddad et al., 2011). Although most reviews on vegetational diversity in agriculture (Russell, 1989; Andow, 1991; Landis et al., 2000; Wäckers et al., 2007; Jonsson et al., 2008; Letourneau et al., 2011; Ratnadass et al., 2012) have concluded that increased diversity is associated with higher natural enemy populations, interpretations vary with respect to herbivore injury, with some attesting a trend towards lower herbivore injury (Letourneau et al., 2011), and others indicating that there is little evidence for this (Jonsson et al., 2008). Part of the reason for this is, no doubt, the wide variety of diversification schemes.

Perennial cropping systems can be diversified by managing non-crop vegetation, within or adjacent to the cultivated area, or by preserving adjacent native vegetation. Within field vegetation consists of planted cover crops or naturalized (i.e. non-native, but established) vegetation; this has the advantage of having a more uniform distribution of any beneficial effect throughout the field, yet drawbacks include possible competition with the commercial crop or interference with crop management. The alternative is the planting or preservation of field margin vegetation, i.e.

\footnotetext{
*Corresponding author: E-mail address: mcostell@calpoly.edu, Current address: Wine and Viticulture Department, California Polytechnic State University

Acknowledgements: The authors thank Prahlada Papper and Mark Welch for their data collection and compilation efforts in the field and laboratory. We are grateful to the Benziger Family Winery, the Milovina family, the McNabb family and the Fetzer Winery for providing vineyard study sites. This project was funded by a grant from the National Fish and Wildlife Foundation, with collaboration from the California Sustainable Winegrowing Alliance
} 
perennial hedgerows or native vegetation areas which border the cropping system, to provide stable natural enemy habitat. However, in most systems it is not known how far any effect will carry from the border into the cultivated area. When effects have been found, they tended to have a limit from the border vegetation into the main crop, estimated by previous studies at $40 \mathrm{~m}$ (Thompson \& Hoffman, 2013) or $60 \mathrm{~m}$ (Griffiths et al., 2008).

In commercial grape vineyards, several studies have been conducted in California on the role of border vegetation on the western grape leafhopper (WGLH), Erythroneura elegantula Osborn (Hemiptera: Cicadellidae) and its major parasitoids, Anagrus erythroneurae S. Trjapitzin \& Chiappini and Anagrus daanei Triapitsyn (Hymenoptera: Mymaridae). This community is an excellent one for testing the influence of vegetational borders, not only because the non-crop vegetation may provide food resources for the natural enemies, but WGLH and Anagrus spp. migrate in the autumn and overwinter on non-grape vegetation (Daane et al., 2013), and therefore nearby alternative vegetation might play a role in providing shelter and overwintering sites. WGLH feeds in the adult and nymphal stages by sucking out the contents of cells in the mesophyll region, which can lead to a reduction in photosynthetic activity. Leafhopper eggs are laid just under the leaf epidermis, and are parasitized by Anagrus spp. WGLH overwinters as an adult and feeds on weedy and perennial evergreen vegetation during the winter; Anagrus spp. overwinter by ovipositing into the eggs of non Erythroneura leafhopper species. Corbett and Rosenheim (1996) studied the effect of a prune tree border as an overwintering refuge for Anagrus spp., finding that the refuge contributed significantly to immigrating Anagrus spp., and also created a windstream that generated a pattern of Anagrus spp. abundance immediately downwind of the refuge. Nicholls et al. (2001) and Wilson et al. (2015a) studied the effects of permanent border vegetation (flowering vegetational corridors or native riparian areas) on WGLH and Anagrus spp., each finding that the border vegetation contributed to lower leafhopper abundance in the most adjacent plot. However, a positive effect on Anagrus spp. density was not found by Nicholls et al. (2001), and was found by Wilson et al. (2015a) only in the early season. Wilson et al. (2015b) found an early season enhancement of Anagrus spp. when analyzing the effects of landscape diversity. Gaigher et al. (2015) studied the influence of natural scrubland of South Africa on hymenopteran parasitoid abundance and diversity in an adjacent commercial vineyard, finding that the parasitoid assemblage differed considerably between the natural area and the vineyard. In Israel, Shapira et al. (2018) found that a vineyard adjacent to a natural area supported high densities of natural enemies during the growing season, and high numbers of Anagyrus sp. nr. pseudoccoci (the main parasitoid of the vine mealybug, Planococcus ficus) in winter.

Results on studies of the effects of vegetational diversity on generalist arthropod predators in vineyards have been mixed. Judt et al. (2019) found that landscape diversity had a positive influence on spider abundance, but not other generalist predators, in Andalusian vineyards. Thomson and Hoffman $(2009,2013)$ found a trend of higher density of a number of generalist predators on vines closest to a woody vegetation border, including coccinellids, staphylinids and predatory thrips, although Thomson et al. (2010) did not find a consistent effect of landscape diversity on vineyard generalist predators. Nichols et al. (2001) found a trend towards higher densities of generalist predator groups, including coccinellids, nabids, chrysopids and syrphids, on vines closest to forested borders or flowering corridors. Wilson et al. (2015b) did not find a significant correlation between landscape diversity and genera such as Orius and Chrysoperla, although in a separate study they did find a positive effect of flowering cover crops on these groups, and found that the only predatory group positively affected was Orius spp. (Wilson et al., 2017).

We studied four commercial vineyard sites in northern California and analyzed the influence of vegetational borders on density of WGLH, Anagrus spp. and generalist predators. Our field sites spanned a range of vegetational diversity: two had planted, highly diverse, perennial flowering hedgerows, one had a diverse natural riparian zone as a border, and one was bordered by a sparse row of two species of native trees. Agroecosystem theory states that vegetative zones with the most diversity, and providing floral resources, would be the most attractive to and harbor more natural enemies (Bianchi \& Wäckers, 2008). We also recorded generalist arthropod predators, most of which were not abundant enough to be analyzed statistically; however, Leptothrips mali (Fitch) (Thysanoptera: Phlaeothripidae) and Orius spp. (Hemiptera: Anthocoridae), were found in sufficient density and are presented here. Our objectives were to evaluate densities of these insects in relation to proximity to vegetational borders, as well as seasonality.

\section{MATERIALS AND METHODS \\ Field sites}

Details of the field sites are summarized in Table 1, and consisted of three sites within the Russian River Valley near Hopland, Mendocino County: Bonterra (McNab Ranch), Fetzer (Sundial Ranch) and Milovina, and one site near Glen Ellen, Sonoma County: Benziger.

Vegetation represented at the study sites is listed in Table 2; the borders at Bonterra and Benziger consisted of a hedgerow or shelterbelt of a diversity of primarily exotic perennials, designed so that at least one component of the planting was in flower over the course of the grape growing season (1 April to 30 October). At Bonterra the vegetation was established as a linear hedgerow along the western border of the vineyard, whereas at Benziger a shelterbelt was planted in the middle of the vineyard in a circular pattern. The Fetzer vineyard was located along the Russian River and the border vegetation consisted primarily of native riparian perennials (Table 2).

The Milovina site was the least diverse of all, and the margin consisted of a southern border of five established native oak trees (valley oak, Quercus lobata) and one native poplar (Fremont poplar, Populus fremontii), with all of the understory vegetation removed. No insecticides were applied at any site; the only pesticides applied on the vines were fungicides for control of powdery mildew (Erysiphe necator) (Table 1). 
TABLE 1

Vineyard study site locations, grape variety and rootstock, type of vegetational border, distance to vineyard edge and summary of fungicide use (for control of Erysiphe necator).

\begin{tabular}{|c|c|c|c|c|}
\hline Vineyard & Location & Variety/rootstock & $\begin{array}{l}\text { Vegetational border/distance to } \\
\text { vineyard edge }\end{array}$ & Pesticides \\
\hline Bonterra & $\begin{array}{l}\text { Russian River Valley, } \\
\text { Mendocino County }\end{array}$ & Merlot/5C & $\begin{array}{l}\text { Mostly exotic perennial hedgerow } \\
\text { on western border/three meters }\end{array}$ & Sulfur and copper \\
\hline Fetzer & $\begin{array}{l}\text { Russian River Valley, } \\
\text { Mendocino County }\end{array}$ & Chardonnay/AxR1 & $\begin{array}{l}\text { Mostly native riparian zone on } \\
\text { western border/ten meters }\end{array}$ & $\begin{array}{l}\text { Horticultural oil } \\
\text { Sulfur }\end{array}$ \\
\hline Benziger & $\begin{array}{l}\text { Glen Ellen, Sonoma } \\
\text { County }\end{array}$ & Sauvignon blanc & $\begin{array}{l}30 \mathrm{~m} \text { diameter shelterbelt, mostly } \\
\text { exotic perennial planting/ten meters }\end{array}$ & $\begin{array}{l}\text { Bacillus subtilis } \\
\text { (Serenade }() \\
\text { Sulfur }\end{array}$ \\
\hline Milovina & $\begin{array}{l}\text { Russian River Valley, } \\
\text { Mendocino County }\end{array}$ & Chardonnay & $\begin{array}{l}\text { Six mature native trees (five valley } \\
\text { oaks, } Q \text {. lobata, and one Fremont } \\
\text { cottonwood, } P \text {. fremontii, on the } \\
\text { southern border /ten meters }\end{array}$ & $\begin{array}{l}\text { Myclobutanil (Rally®) } \\
\text { Sulfur }\end{array}$ \\
\hline
\end{tabular}

Single row plots were established at each site along a gradient from the border vegetation. The distance from the border vegetation to the vineyard edge (i.e., the roadway used for vehicle and equipment transport) was approximately $10 \mathrm{~m}$ at Fetzer, Milovina and Benziger, and $3 \mathrm{~m}$ at Bonterra (Table 1), and four adjacent plots were sampled at $20 \mathrm{~m}$ increments (i.e., $30 \mathrm{~m}, 50 \mathrm{~m}, 70 \mathrm{~m}$ and $90 \mathrm{~m}$ from the border vegetation).

\section{Data collection}

At each site, we counted leafhopper nymphs on 30 leaves per plot every two weeks, from April to September 2007. To collect Anagrus spp. and generalist predators, we placed one yellow sticky card $(178 \mathrm{~mm}$ x $101 \mathrm{~mm}$, Seabright, Emeryville, CA, USA) within the vine canopy of the $10 \mathrm{~m}$ plot (i.e. the border plot), and in the $30 \mathrm{~m}, 50 \mathrm{~m}, 70 \mathrm{~m}$ and $90 \mathrm{~m}$ plots. We changed cards every two weeks and recorded adults per card.

\section{Data analysis}

Leafhopper nymphs per leaf, Anagrus spp. per card and pooled Orius spp./L. mali per card were log10 transformed and analyzed by analysis of variance (ANOVA), using a mixed linear model, using site, distance and the interaction between site and distance as fixed effects and date as a random effect (PROC MIXED, SAS Institute 2012), and using least squared means with the Tukey adjustment for mean separation. Orius spp. and L. mali data were pooled for illustrative purposes, as the results did not differ from separate analyses. Anagrus spp. and Orius spp./L. mali were analyzed by early and late season time periods, which corresponded to analysis of the first and second leafhopper generations, which were estimated by site and defined by date range in Table 3. The ANOVA was considered statistically significant at $\mathrm{p}<0.05$.

Mean Anagrus spp., Orius spp. and L. mali per card $(\log 10)$ were regressed against mean leafhopper nymphal density per leaf $(\log 10)$ on each sampling date for the early to mid season and mid to late season time period (corresponding to the first and second leafhopper generations), pooling the data across all sites (PROG REG, SAS Institute 2012). Orius spp. and $L$. mali data were not pooled for the regressions.

\section{RESULTS}

\section{Leafhopper density}

Mean first generation leafhopper density (across all dates for each distance) was highest at Bonterra (3.0 nymphs/leaf) and lowest at Fetzer ( 0.38 nymphs/leaf), with no nymphs counted at Benziger (Fig. 1), whereas mean second generation leafhopper density was highest at Milovina (1.26 nymphs/ leaf) and lowest at Benziger (0.06 nymphs/leaf) (Fig. 2).

At three of the four sites, leafhopper nymphal density decreased from first to second generations, independent of Anagrus spp. density. Except for Benziger, where few leafhoppers were counted, second generation nymphal density was $63.5,75.5$, and $26 \%$ lower at Fetzer, Bonterra, Milovina, respectively, compared to the first generation $(p<0.001)$. For first generation leafhoppers, there was significant interaction between site and distance $(\mathrm{F}=$

2.87, $\mathrm{df}=8,2081, \mathrm{p}=0.004)$, in that at the Bonterra site nymphal density in the border plot was an average of $43.8 \%$ lower than in the $70 \mathrm{~m}$ or $90 \mathrm{~m}$ plots $(\mathrm{p}<0.001)$, but there was no significant distance effect at the other sites (Fig. 1). There was also significant interaction between site and distance for second generation nymphal density $(\mathrm{F}=15.86, \mathrm{df}=8$, 2230, $\mathrm{p}<0.001$ ), again the effect being at Bonterra, but the trend reversed from the first generation: nymphal density in the border plot was significantly higher than all other plots, by $1.17,1.81,2.88$ and 4.43 fold, compared to the $30 \mathrm{~m}$, $50 \mathrm{~m}, 70 \mathrm{~m}$ and $90 \mathrm{~m}$ plots, respectively (p<0.001, Fig. 2). This resulted because leafhopper density in the border plot remained the same between generations $(p=0.815)$, whereas density declined at all other distances from first to second generation $(\mathrm{p}<0.001)$ (Figs. 1 and 2$)$. In addition, second generation leafhopper density in the $30 \mathrm{~m}$ plot was $78.5 \%$ higher than at $70 \mathrm{~m}(\mathrm{p}=0.039)$ and 1.47 fold higher than at $90 \mathrm{~m}(\mathrm{p}<0.001)$ (Fig. 2). There were no significant distance effects in second generation leafhopper nymphal density at the other sites (Fig. 2). 
TABLE 2

List of plant species and associated families in the vegetative borders at the vineyard study sites.

\begin{tabular}{|c|c|c|c|}
\hline Site & Family & Species & \\
\hline \multirow[t]{19}{*}{ Bonterra } & Asteraceae & Foeniculum vulgare & Gaillardia sp. \\
\hline & & Echinacea purpurea & Chrysanthemum parthenium \\
\hline & & Achillea millefolium & Coreopsis verticillata \\
\hline & & Artemisia sp. & Aster frikartii \\
\hline & Buddlejaceae & Buddleia davidii & \\
\hline & Euphorbiaceae & Euphorbia lathyris & \\
\hline & Lamiaceae & Rosmarinus officinalis & Nepeta $x$ fassenii \\
\hline & & Origanum vulgare & Lavendula spp. \\
\hline & Linaceae & Linum perenne & \\
\hline & Lythraceae & Punica granatum & \\
\hline & Moraceae & Ficus carica & \\
\hline & Myrtaceae & Feijoa sellowiana & \\
\hline & Onagraceae & Gaura lindheimeri & \\
\hline & Poaceae & Cortaderia selloana & Stipa arundinacea \\
\hline & & Digitaria sanguinalis & \\
\hline & Rosaceae & Prunus persica & Rosa sp. \\
\hline & & Mespilus germanica & \\
\hline & Salicaceae & Salix exigua & \\
\hline & Verbenaceae & Verbena peruviana & \\
\hline \multirow[t]{10}{*}{ Fetzer } & Anacardiaceae & Rhus diversiloba & \\
\hline & Apiaceae & Conium maculatum & \\
\hline & Caprifoliaceae & Dipsacus sylvestris & \\
\hline & Caprifoliaceae & Symphoricarpos albus & \\
\hline & Fagaceae & Quercus lobata & \\
\hline & Juglandaceae & Juglans hindsii & \\
\hline & Oleaceae & Fraxinus latifolia & \\
\hline & Rosaceae & Rubus procerus & Rosa multiflora \\
\hline & Salicaceae & Salix exigua & Populus fremontii \\
\hline & Sapindaceae & Acer negundo & \\
\hline \multirow[t]{8}{*}{ Benziger } & Asparagaceae & Yucca gloriosa & \\
\hline & Asteraceae & Achillea tomentosa & Rudbeckia hirta \\
\hline & & Ratibida columnifera & Echinacea purpurea \\
\hline & Lamiaceae & Hyssopus officinalis & Nepeta $x$ faassenii \\
\hline & & Salvia spp. & Perovskia atriplicifolia \\
\hline & Onagraceae & Epilobium canum & \\
\hline & Plantaginaceae & Penstemon spp. & \\
\hline & Xanthorrhoeaceae & Kniphofia uvaria & \\
\hline \multirow[t]{2}{*}{ Milovina } & Fagaceae & Quercus lobata & \\
\hline & Salicaceae & Populus fremontii & \\
\hline
\end{tabular}




\section{Anagrus spp. density}

Early season Anagrus spp. density was highest at Bonterra (34.3 Anagrus spp./card) and lowest at Benziger (2.95 Anagrus spp./card) (Fig. 3), whereas late season density was highest at Milovina (296 Anagrus spp./card) and lowest at Benziger (8.6 Anagrus spp./card) (Fig. 4).

For early season Anagrus spp. there was no overall distance effect, but there was interaction between site and distance $(\mathrm{F}=2.30, \mathrm{df}=12,57, \mathrm{p}=0.018)$. Only at Bonterra was the distance effect significant, with density in the border plot $54.5 \%$ lower than in the $70 \mathrm{~m}$ plot ( $\mathrm{p}=0.022$, Fig. 3 ). For late season Anagrus spp. there was an overall distance effect $(\mathrm{F}=3.67, \mathrm{df}=4,76, \mathrm{p}=0.008)$, with the border plot $17.2 \%$ higher than the $30 \mathrm{~m}$ plot $(\mathrm{p}=0.01)$ and $32.8 \%$ higher than the $50 \mathrm{~m}$ plot $(\mathrm{p}=0.018)$, and no interaction between site and distance, although the effect was clearly driven by the Fetzer, Bonterra and Benziger sites (Fig. 4).

\section{Leptothrips mali and Orius spp. density}

Early season density of the generalist predators L. mali and Orius spp. was significantly higher at the Fetzer site than at the other sites (2.8 times higher than at Bonterra or Milovina, and 19.6 times higher than Benziger) $(\mathrm{p}<0.01$, Fig. 5), but there was no effect of distance and no interaction between site and distance. Late season generalist predator density was significantly higher at the Milovina site than the other sites (3.8 times higher than at Bonterra and 17.6 times higher than at Fetzer or Benziger) $(p<0.001$, Fig. 6). In addition, late season predator density at Bonterra was 4.6 times higher than at Fetzer or Benziger $(p<0.001$, Fig. 6). There was no significant effect of distance on late season predatory density, nor was there interaction between distance and site.

\section{Regression analyses}

Regression analysis showed a positive relationship between Anagrus spp. density and nymphal density for the first leafhopper generation $(\mathrm{y}=0.44+1.31 \mathrm{x}, \mathrm{p}<0.001)$, as well as the second leafhopper generation $(\mathrm{y}=1.30+2.87 \mathrm{x}$, $\mathrm{p}<0.001$ ) (Fig. 7). Leafhopper density explained $67 \%$ of Anagrus spp. density in the first leafhopper generation and $73 \%$ in the second generation (Fig. 7).

There was a negative relationship between Orius spp. density and leafhopper nymphal density for the first leafhopper generation $(y=1.12-1.15 x, p=0.003)$, with $47 \%$

TABLE 3

Sampling date ranges (2007) for analysis of early and late season Anagrus spp. density, corresponding to the first and second generations of leafhoppers.

\begin{tabular}{|c|c|c|}
\hline Site & Early season $/ \mathbf{1}^{\text {st }}$ leafhopper generation & Late season $/ 2^{\text {nd }}$ leafhopper generation \\
\hline Fetzer & 30 May-6 July & 20 July-14 Sept \\
\hline Bonterra & 21 May-29 June & 13 July-7 Sept \\
\hline Milovina & 30 May-9 July & 30 July-20 Sept \\
\hline Benziger & 20 April-14 June & 29 June-22 Sept \\
\hline
\end{tabular}

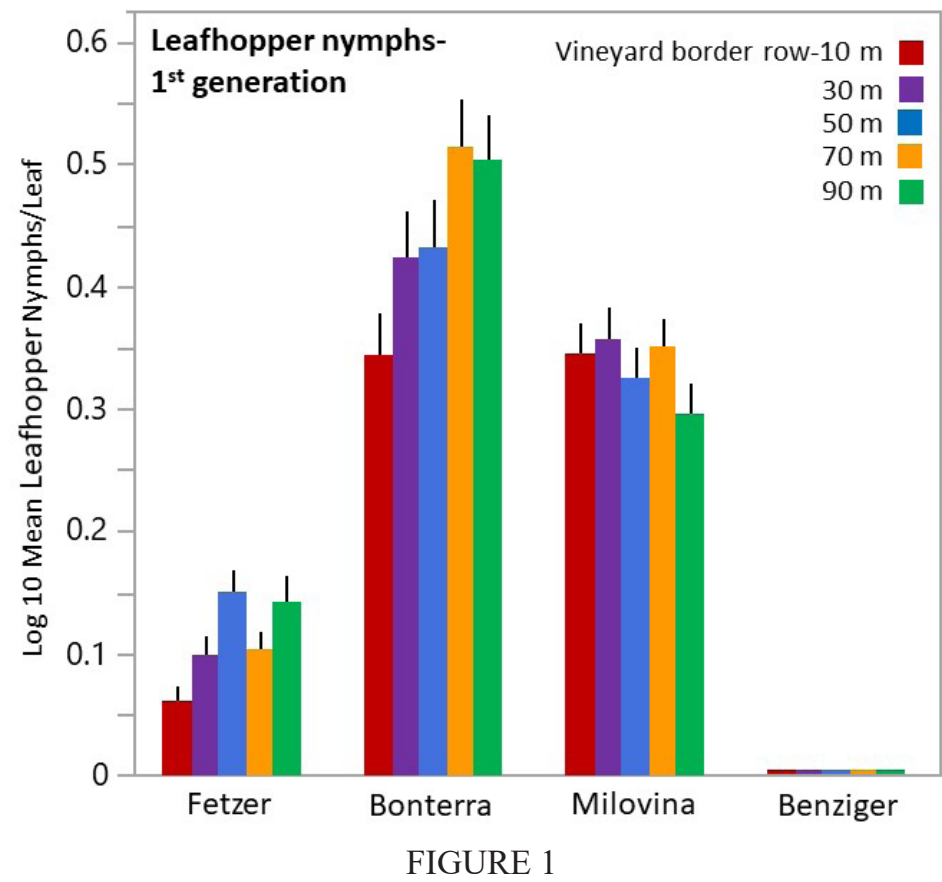

Mean first generation leafhopper nymphal density ( $\log 10$ mean \pm standard error of the mean) by site and distance. At Bonterra, leafhopper density in the border plot averaged $43.8 \%$ lower than the $70 \mathrm{~m}$ or $90 \mathrm{~m}$ plots $(\mathrm{p}<0.001)$. 


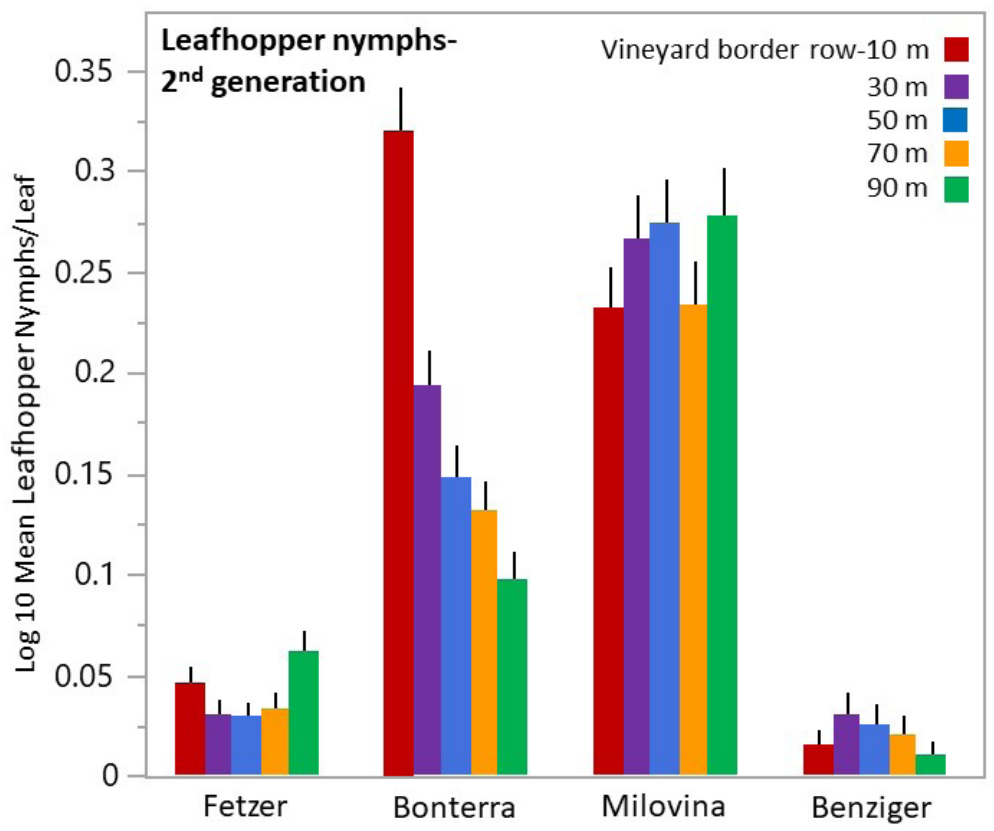

FIGURE 2

Mean second generation leafhopper nymphal density ( $\log 10$ mean \pm standard error of the mean) by site and distance. At Bonterra, leafhopper density in the border plot was 1.17, 1.81, 2.88 and 4.43 fold higher, compared to the $30 \mathrm{~m}, 50 \mathrm{~m}, 70 \mathrm{~m}$ and $90 \mathrm{~m}$ plots, respectively $(\mathrm{p}<0.001)$.

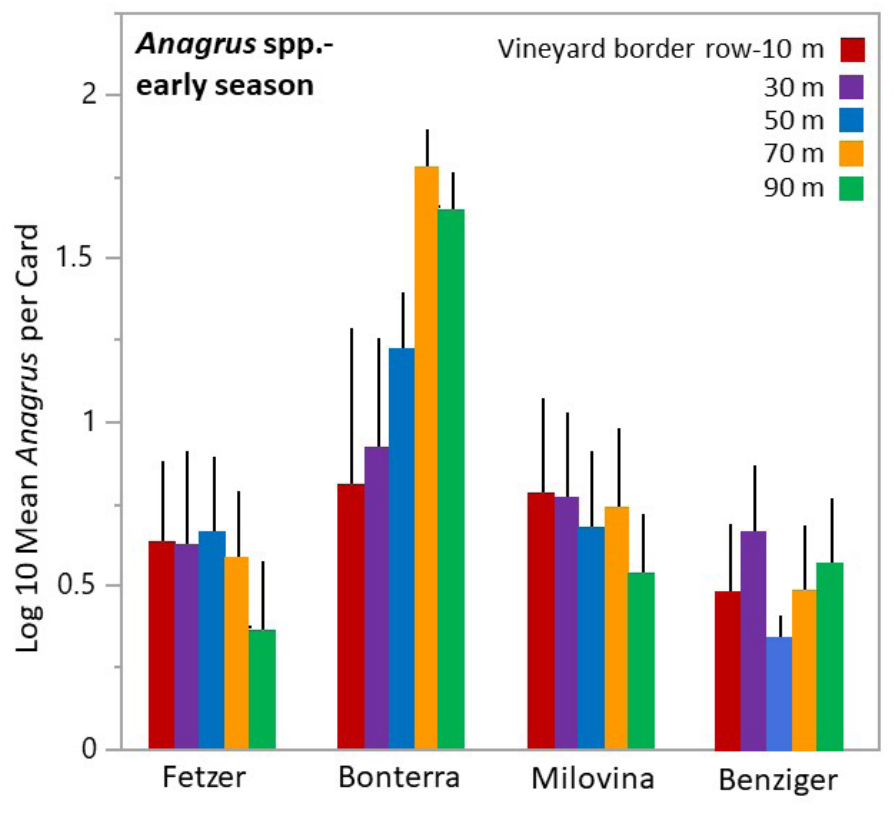

FIGURE 3

Mean early season Anagrus spp. density ( $\log 10$ mean \pm standard error of the mean) by site and distance. At Bonterra density in the border plot was $54.5 \%$ lower than the $70 \mathrm{~m}$ plot $(\mathrm{p}=0.022)$.

of variability explained, but no significant relationship for the second leafhopper generation $(\mathrm{p}=0.602)$ (Fig. 8).

There was no significant relationship between L. mali density and leafhopper nymphal density for the first leafhopper generation $(\mathrm{p}=0.15)$, but there was a positive relationship in the second leafhopper generation $(y=-0.13$ $+3.01 \mathrm{x}$ ), with $67 \%$ of the variability explained by the model (Fig. 9).

\section{DISCUSSION}

This study provides evidence that a vegetationally diverse border can influence density of WGLH and Anagrus spp., supporting the studies of Wilson et al. (2015a, 2015b, 2017) and Nichols et al. (2001). Several responses were revealed when the data were analyzed by site, leafhopper generation or time of the season. First, leafhopper nymphal density in both generations was significantly affected by the hedgerow at Bonterra: compared to the other sampling distances, 


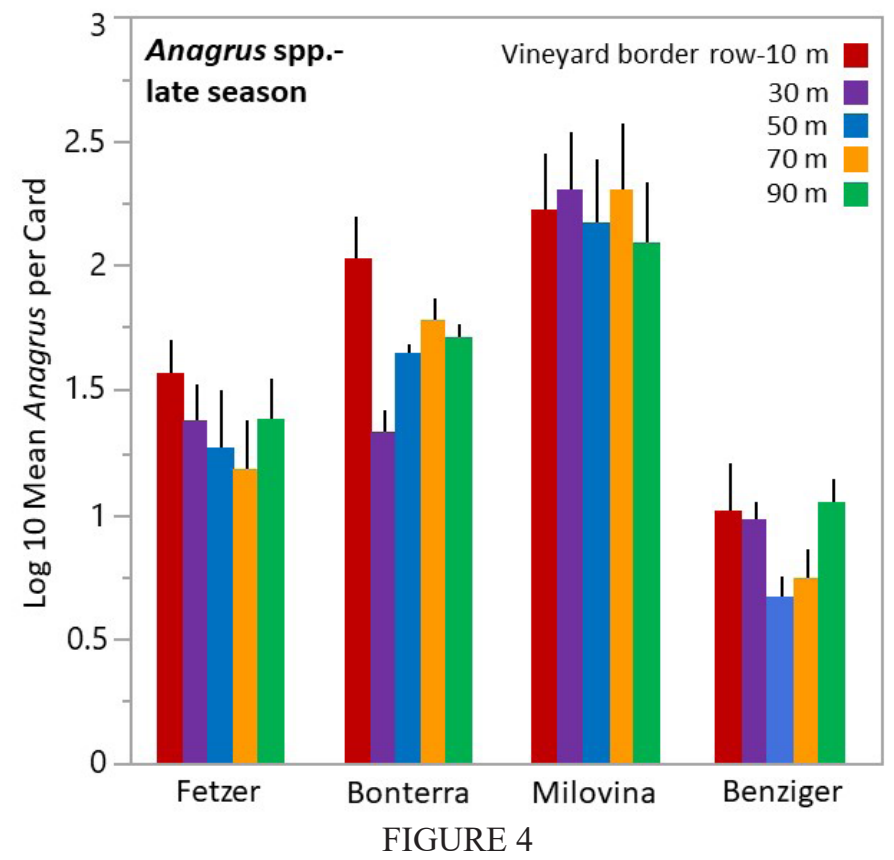

Mean late season Anagrus spp. density ( $\log 10$ mean \pm standard error of the mean) by site and distance. Across all sites, density in the border plot was $17.2 \%$ higher than in the $30 \mathrm{~m}$ plot $(\mathrm{p}=0.01)$ and $32.8 \%$ higher than in the $50 \mathrm{~m}$ plot $(\mathrm{p}=0.018)$.

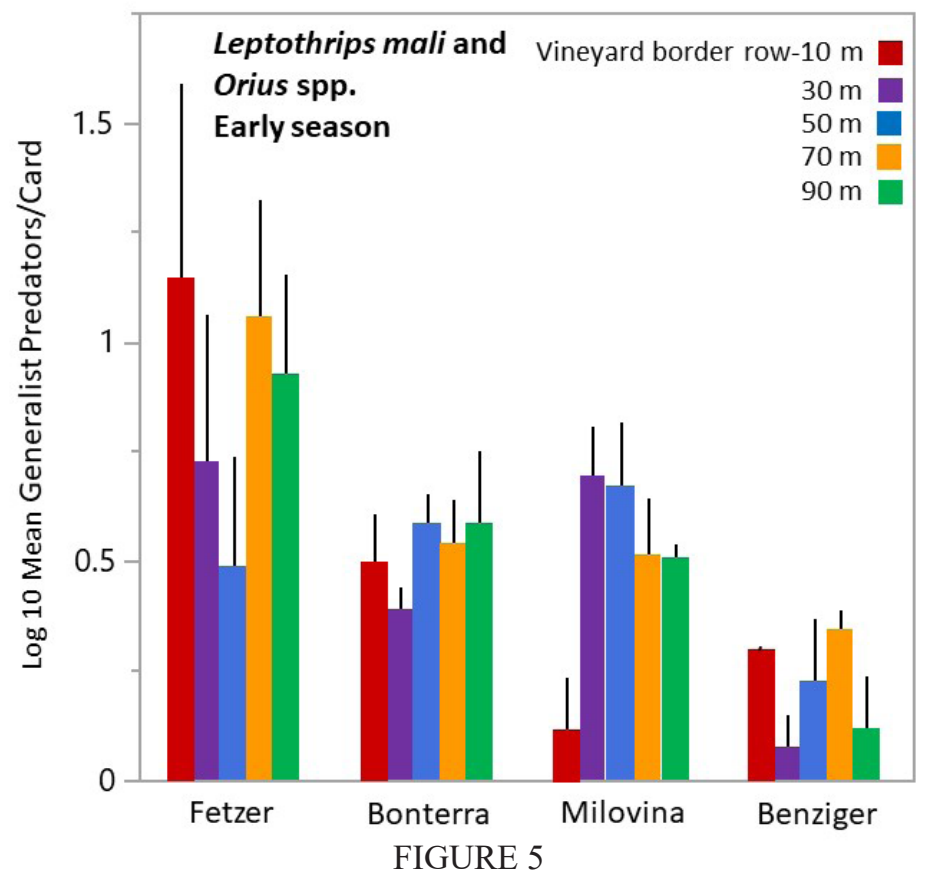

Mean early season density of Leptothrips mali and Orius spp. (log10 mean \pm standard error of the mean) by site and distance.

There was no significant effect of border vegetation on these generalist predators.

leafhopper density was lowest nearest the border in the first generation, but highest in the second generation. In similar studies, Wilson et al. (2015a) found lower density of first generation nymphs adjacent to a riparian border and Nicholls et al. (2001) found lower density of second generation nymphs adjacent to a flowering hedgerow. Also, at Bonterra (hedgerow) and Fetzer (riparian) it is interesting that the effect on leafhopper density in the vineyard border row was consistent between generations: at all other sampling distances, leafhopper density declined from first to second generation. This was not the case at Milovina (low-diversity tree row), where leafhopper density declined from first to second generations at all distances. The explanation for this generational decline is not known, but the results provide additional evidence that a diverse vegetational border can impact leafhopper populations. Secondly, the only early season effect on Anagrus spp. was at Bonterra (hedgerow), with density highest in the plots farthest away from the 
border. This finding runs counter to the concept that Anagrus spp. migration from its overwintering habitat would produce a density gradient (Doutt and Nakata, 1965; Murphy et al. 1996, 1998), resulting in highest Anagrus spp. activity on vines closest to the overwintering refuge, as found by Corbett and Rosenheim (1996). It is possible that in the current study the vegetational border produced a windstream that carried Anagrus spp. away from the margins and farther into the vineyard. Finally, there was a trend toward higher late season density of Anagrus spp. nearest the border (at Bonterra [hedgerow], Fetzer [riparian] and Benziger [shelterbelt], but not at Milovina [low-diversity tree row]). Interestingly,
Wilson et al. (2017) also found a seasonal effect of noncrop vegetation (within vineyard flowering cover crops) on Anagrus spp. density, the effect being positive early season, but with no late season effect. In the current study, the high late season Anagrus spp. density in the vineyard border plot was not likely due to the border vegetation, since at that point in the season conditions and resources for this parasitoid are largely met within the vineyard.

None of these findings suggest that the influence of the vegetational border on Anagrus spp. explained leafhopper abundance: the seasonal patterns of Anagrus spp. and leafhopper abundance at Bonterra (hedgerow)

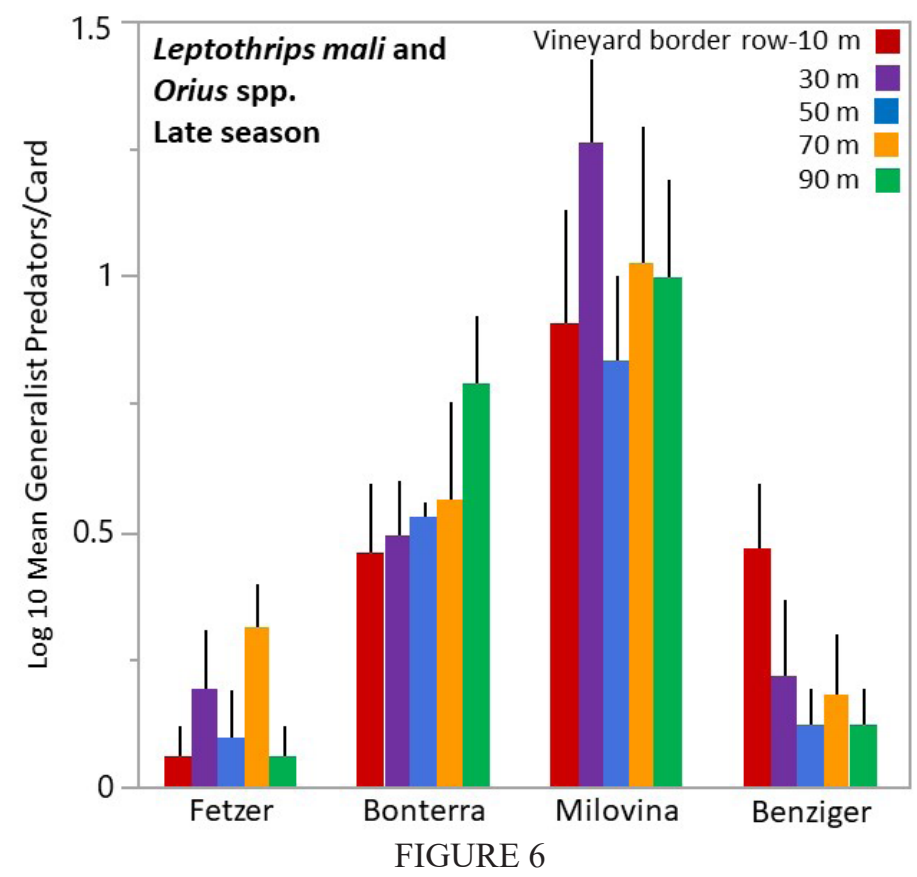

Mean late season density of Leptothrips mali and Orius spp. (log10 mean \pm standard error of the mean) by site and distance.

There was no significant effect of border vegetation on these generalist predators.

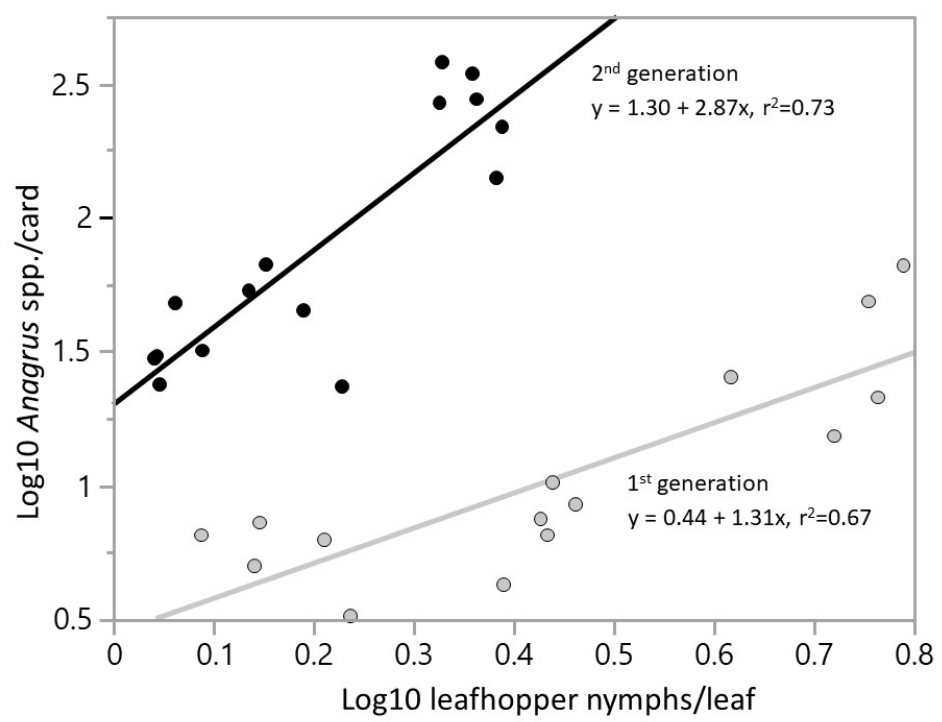

FIGURE 7

Regression of $\log 10$ Anagrus spp. density against log10 leafhopper nymphal density for the first (gray regression line) and second (black regression line) leafhopper generations. The regressions were positive and significant $(\mathrm{p}<0.05)$. 


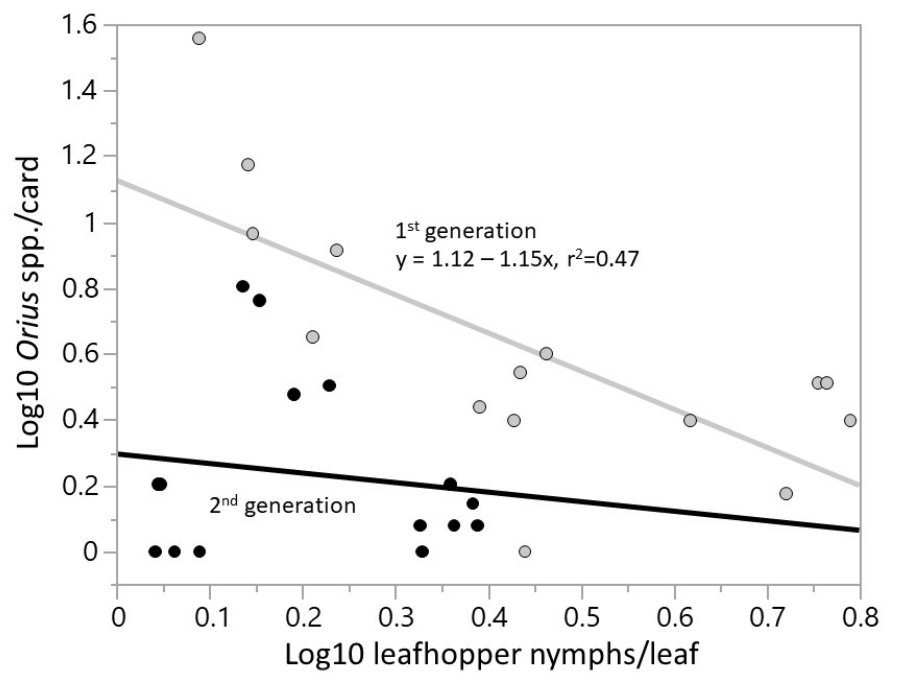

FIGURE 8

Regression of $\log 10$ Orius spp. density against $\log 10$ leafhopper nymphal density for leafhopper generations one (gray regression line, negatively significant at $\mathrm{p}=0.003$ ) and two (black regression line, not significant at $\mathrm{p}=0.602$ ).

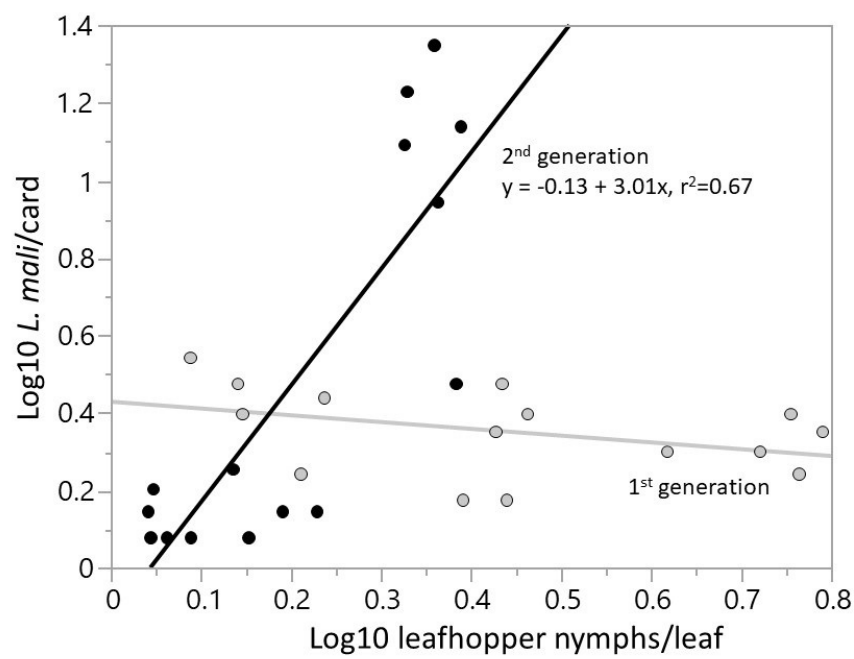

FIGURE 9

Regression of $\log 10$ Leptothrips mali density against log10 leafhopper nymphal density for leafhopper generations one (gray regression line, not significant at $\mathrm{p}=0.156$ ) and two (black regression line, positively significant at $\mathrm{p}<0.001$ ).

were in opposition, and the overall trend toward higher late season Anagrus spp. density in the border plot did not correspond to lower leafhopper density. It appears then, that the primary influence of the vegetational borders was on leafhopper density, and that the pattern of Anagrus spp. was due to a density dependent response to the leafhoppers. This is evidenced in the regressions of Anagrus spp. against leafhopper density, which were significantly positive in both generations, and explained a relatively high percentage of variability (67\% and $73 \%$ in the first and second generations, respectively, Fig. 7). Likewise, Nicholls et al. (2001) and Wilson et al. (2015a) found a pattern of higher leafhopper nymphal density and corresponding parasitism by Anagrus spp. (in each of these studies the effect was in the vineyard interior rather than the vines closest to border vegetation), which also suggests a density dependent response. Therefore, what seems to best explain Anagrus spp. abundance with respect to border vegetation is an indirect effect, the functional and numerical responses to WGLH density (which was affected by the vegetational border), rather than a direct influence.

In the current study there was no significant effect of the vegetational borders on the generalist predators analyzed, namely L. mali and Orius spp. Nicholls et al. (2001) attributed lower leafhopper density on vines near a vegetational corridor to the predatory impact of Coccinellidae, Syrphidae, Chrysopidae, Nabidae and, within the Anthocoridae, Orius spp. However, this conclusion does not appear to be justified, given that one of these families (the Syrphidae) does not feed on WGLH, three of them (Coccinellidae, Chrysopidae and Nabidae) are rarely if ever observed feeding on WGLH nymphs, and, with the exception of Orius spp., these natural enemy groups are typically found at such low densities in California vineyards (Costello \& Daane, 1999) that they 
likely have little to no significant effect on population suppression of WGLH. Wilson et al. (2015a) found a late season response to the border by Orius spp., but admitted that the relatively low density of these predators made it difficult for the authors to analyze the data, much less conclude that generalist natural enemies played a role in leafhopper density. Whereas at our field sites L. mali and Orius spp. reached densities per card comparable to Anagrus spp. (e.g., Fetzer [riparian] early season, Fig. 5, and Milovina [lowdiversity tree row] late season, Fig. 6), it is not clear they had an impact on leafhopper density. In fact, regression analysis showed a negative relationship between Orius spp. and first generation leafhopper density, and no significant relationship in the second generation, suggesting that these predators had little impact on the leafhopper population. Interestingly, Wilson et al. (2017) found a negative relationship between early season Orius spp. density and leafhopper abundance, although the trend reversed in the late season. And, although in our study there was a positive relationship between L. mali and second generation leafhopper density, L. mali is primarily known as a mite predator and pollen feeder (Parella et al., 1982), and there have been no recorded observations of this thrips species feeding on E. elegantula nymphs; therefore its impact on leafhopper population density is uncertain.

If the effect of the vegetational border on leafhopper populations in the current study was not due to natural enemies, what might explain it? Wilson et al. (2015a) suggested that decreased vigor of the border vines led to lower leafhopper oviposition. It is well known that leafhoppers are sensitive to vine water status (Daane \& Williams, 2003) and lay fewer eggs on water stressed vines (Costello, 2008), and therefore competition for water with the non vine vegetation could have increased water stress of the border vines. It is also possible that root associations, or additional amounts of shade at the vegetative borders, could have influenced border plot vines, which lead to vine physical or chemistry differences, affecting leafhopper oviposition or nymphal survivorship. In the current study, vine status differences could explain the lower early season leafhopper density in the border plot at Bonterra (hedgerow), and even at Fetzer (riparian), which, although not significantly different, shows the same trend. And, the fact that at Bonterra (hedgerow) leafhopper density declined from first to second generations at all distances except the border plot (and although not statistically significant, the trend was the same at Fetzer [riparian]), suggests that border plot vines were distinct from the rest of the vineyard, leading to differences in leafhopper density.

The results of this study do not lead us to conclude that vegetative corridors, borders or shelterbelts cannot influence Anagrus spp. density in nearby vineyards. Known Anagrus spp. overwintering host plants include Rubus spp. and Prunus spp. (Doutt \& Nakata, 1965; Kido et al., 1984), as well as Salix spp. and Rosa spp. (Wright \& James, 2007; Prischmann et al., 2007). In addition, some nectar bearing plants appear to enhance Anagrus spp. populations: Wilson et al. (2017) found that flowering cover crops (Phacelia tanacetifolia, Ammi majus and Daucus carota) increased early season Anagrus spp. density, and we found similar results with a cover crop of alyssum (Lobularia maritima) (Costello, Thrupp \& McGourty, unpublished data). Wilson et al. (2016) found high winter and spring abundance of Anagrus spp. on the perennial Baccharis pilularis, which produces abundant nectar. We agree with Wilson et al. (2016) that the impact of alternative vegetation on Anagrus spp. will depend on the type and frequency of favored Anagrus spp. host plants in the vegetational border or corridor. Baccharis pilularis was not present at any of our sites, and although Rubus procerus and Rosa multiflora were present in the native border at our Fetzer (riparian) site, they may not have been present in high enough density to augment early season Anagrus spp. density in the vineyard.

\section{CONCLUSIONS}

Our results show that there can be an effect of border vegetation on vineyard leafhopper populations, which support findings in similar studies. In our study, at two sites with a diverse vegetative border, the result was a fairly stable seasonal population of leafhoppers in the vineyard border rows, whereas otherwise leafhopper density decreased between the first and second generations, and this effect was not seen at the low-diversity vegetation border site. Our results provide no evidence that the impact of the border vegetation was on Anagrus spp. or generalist predators, rather, they suggest that the border vegetation had an undetermined influence on vine condition in the border rows, which affected leafhopper oviposition or nymphal survivorship.

\section{LITERATURE CITED}

Andow D., 1991. Vegetational diversity and arthropod population response. Annu. Rev. Entomol. 36, 561-586.

Bianchi, F.J.J.A. \& Wäckers, F., 2008. Effects of flower attractiveness and nectar availability in field margins on biological control by parasitoids. Biol. Control 46, 400-408.

Corbett, A. \& Rosenheim, J.A., 1996. Impact of a natural enemy overwintering refuge and its interaction with the surrounding landscape. Ecol. Entomol. 21, 155-164.

Costello, M.J. \& Daane, K.M., 1999. Abundance of spiders and insect predators on grapes in central California. J. Arachnology 27, 531-538.

Costello, M.J., 2008. Regulated deficit irrigation and density of Erythroneura spp. (Hemiptera: Cicadellidae) on grape. J. Econ. Entomol. 101, 1287-1294.

Daane, K.M. \& Williams, L.E., 2003. Manipulating vineyard irrigation amounts to reduce insect pest damage. Ecol. Appl. 13, 1650-1666.

Daane, K.M., Rosenheim, J.A., Smith, R.J. \& Coviello, R.L., 2013. Western Grape Leafhopper. In: Bettiga, L.J. (ed.), Grape Pest Management, $3^{\text {rd }}$ edition. University of California, Agriculture and Natural Resources Publication 3343, Richmond, CA, USA, pp. 202-219.

Doutt, R.L. \& Nakata, J., 1965. Overwintering refuge of Anagrus epos (Hymenoptera: Mymaridae). J. Econ. Entomol. 58, 586.

Gaigher, R., Pryke, J.S. \& Samways, M.J., 2015. High parasitoid diversity in remnant natural vegetation, but limited spillover into the agricultural matrix in South African vineyard agroecosystems. Biol. Conserv. 186, 69-74.

Griffiths, G.J.K., Holland, J.M., Bailey, A. \& Thomas, M.B., 2008. Efficacy and economics of shelter habitats for conservation biological control. Biol. Control 45, 200-209. 
Gurr, G.M., Wratten, S.D., Tylianakis, J., Kean, J. \& Keller, M., 2005 Providing plant foods for natural enemies in farming systems: balancing practicalities and theory. In: Wäckers, F.L., van Rijn, P.C.J. \& Bruin, J. (eds.), Plant-provided Food for Carnivorous Insects: A Protective Mutualism and its Applications. Cambridge University Press, Cambridge, UK, pp. 326-347.

Haddad, N.M., Crutsinger, G.M., Gross, K., Haarstad, J. \& Tilman, D., 2011. Plant diversity and the stability of foodwebs. Ecol. Lett. 14, 42-46.

Jonsson, M., Wratten, S.D., Landis, D.A. \& Gurr G.M., 2008. Recent advances in conservation biological control of arthropods by arthropods. Biol. Control 45, 172-175.

Judt, C.C., Guzmán, G., Gómez, J.A., Cabezas, J.M., Entrenas, J.A., Winter, S., Zaller, J.G. \& Paredes, D., 2019. Diverging effects of landscape factors and inter-row management on the abundance of beneficial and herbivorous arthropods in Andalusian vineyards (Spain). Insects 10. doi:10.3390/ insects 10100320

Kido, H., Flaherty, D., Bosch, D. \& Valero, K., 1984. French prune trees as overwintering sites for the grape leafhopper egg parasite. Am. J. Enol. Vit. $35,156-160$

Landis, D.A., Wratten, S.D. \& Gurr, G.M., 2000. Habitat management to conserve natural enemies of arthropod pests in agriculture. Annu. Rev. Entomol. 45, 175-201.

Letourneau, D.K., Armbrecht, I., Rivera, B.S., Lerma, J.M., Carmona, E.J., Daza, M.C., Escobar, S., Galindo, V., Gutiérrez C., López, S.D., Mejía, J.L. Rangel, A.M.A., Rangel, J.H., Rivera, L., Saavedra, C.A., Torres, A.M. \& Trujillo, A.R., 2011. Does plant diversity benefit agroecosystems? A synthetic review. Ecol. Appl. 21, 9-21.

Murphy, B.C., Rosenheim, J.A. \& Granett, J., 1996. Habitat diversification for improving biological control: abundance of Anagrus epos (Hymenoptera: Mymaridae) in grape vineyards. Environ. Entomol. 25, 495-504.

Murphy, B.C., Rosenheim, J.A., Dowell, R.V. \& Granett, J., 1998. Habitat diversification tactic for improving biological control: parasitism of the western grape leafhopper. Entomol. Exp. Appl. 87, 225-235.

Nicholls, C.I., Parella, M. \& Altieri, M.A., 2001. The effects of a vegetational corridor on the abundance and dispersal of insect biodiversity within a northern California organic vineyard. Landsc. Ecol. 16, 133-146.

Prischmann, D., James, D., Storm, C., Wright, L. \& Snyder, W., 2007. Identity, abundance, and phenology of Anagrus spp. (Hymenoptera: Mymaridae) and leafhoppers (Homoptera: Cicadellidae) associated with grape, blackberry, and wild rose in Washington State. Ann. Entomol. Soc. Am. 100, 41-52.

Ratnadass, A., Fernandes, P., Avelino, J. \& Habib, R., 2012. Plant species diversity for sustainable management of crop pests and diseases in agroecosystems: a review. Agron. Sustain. Develop. 32, 273-303.
Root, R.B., 1973. Organization of a plant-arthropod association in simple and diverse habitats: the fauna of collards (Brassica oleracea). Ecol. Monogr. 43, 95-124.

Russell, E., 1989. Enemies hypothesis: A review of the effect of vegetational diversity on predatory insects and parasitoids. Environ. Entomol. 18, 590599.

Shapira, I., Gavish-Regev, E., Sharon, R., Harari, A.R., Kishinevsky, M. \& Keasar, T., 2018. Habitat use by crop pests and natural enemies in a Mediterranean vineyard agroecosystem. Agric. Ecosyst. Environ. 267, 109-118.

SAS Institute Inc., 2012. SAS for Windows Release 9.4. Cary, NC, USA

Thomson, L.J. \& Hoffmann, A.A., 2009. Vegetation increases the abundance of natural enemies in vineyards. Biol. Control 49, 259-269.

Thomson, L.J. \& Hoffmann, A.A., 2013. Spatial scale of benefits from adjacent woody vegetation on natural enemies within vineyards. Biol. Control 64, 57-65.

Thomson, L.J., McKenzie, J., Sharley, D.J., Nash, M.A., Tsitsilas, A. \& Hoffmann, A.A., 2010. Effect of woody vegetation at the landscape scale on the abundance of natural enemies in Australian vineyards. Biol. Control $54,248-254$

Wäckers, F.L., Romeis, J. \& van Rijn, P., 2007. Nectar and pollen feeding by insect herbivores and implications for multitrophic interactions. Annu. Rev. Entomol. 52, 301-323.

Wilson, H., Miles, A.F., Daane, K.M. \& Altieri, M.A., 2015a. Vineyard proximity to riparian habitat influences Western grape leafhopper (Erythroneura elegantula Osborn) populations. Agric. Ecosyst. Environ. 211, 43-50.

Wilson, H., Miles, A.F., Daane, K.M. \& Altieri, M.A., 2015b. Landscape diversity and crop vigor influence biological control of the western grape leafhopper (E. elegantula Osborn) in Vineyards. PLoS ONE 10, e0141752. doi:10.1371/journal.pone.0141752.

Wilson, H., Miles, A.F., Daane, K.M. \& Altieri, M.A., 2016. Host plant associations of Anagrus spp. (Hymenoptera: Mymaridae) and Erythroneura elegantula (Hemiptera: Cicadellidae) in Northern California. Environ. Entomol. 45, 602-615.

Wilson, H., Miles, A.F., Daane, K.M. \& Altieri, M.A., 2017. Landscape diversity and crop vigor outweigh influence of local diversification on biological control of a vineyard pest. Ecosphere 8, e01736. doi:10.1002/ ecs2.1736.

Wright, L.C. \& James, D.G., 2007. Anagrus spp. (Hymenoptera: Mymaridae) reared from plants collected during winter in south central Washington and north central Oregon. J. Entomol. Soc. B.C. 100, 41-52. 